\title{
Economic Capital as a Means of Coping with the Social Roles of Young Olds ${ }^{1}$
}

\author{
Marcela Petrová Kafková ${ }^{2}$ \\ Institute of State and Law, Praha, Czech Republic \\ Office for Population Studies, Faculty of Social Studies, Masaryk University, \\ Brno, Czech Republic
}

\begin{abstract}
Economic Capital as a Means of Coping with the Social Roles of Young Olds. Young olds are a target group for active ageing policies. They are expected to stay economically active as long as possible, to take care of their family members, and at the same time to engage in leisure and self-development activities. Their activity is expected to promote generational equity. Through these expectations, young olds are homogenized on the basis of age, and important stratification factors such as gender, class, and ethnicity are not considered. In this article, mixed methods are used on the example of young olds in the Czech Republic to argue that young olds are often overloaded by their social roles. The negative effects of role overload mainly affect women with low economic capital. Role harmonization and choices of coping strategies are economically conditioned, despite the relatively flattened pensions.

Sociológia 2019, Vol. 51 (No. 3: 272-289)

https://doi.org/10.31577/sociologia.2019.51.3.13
\end{abstract}

Key words: Age; role overload; active ageing; ageism; Czech Republic; economic capital; gender

\section{Introduction}

The question of age discrimination was raised in the Czech context by Vidovićová (2005) with the statement that 'ageism is an ideology based on a shared belief about the qualitative inequalities of the individual phases of the human life cycle manifested through the process of systematic, symbolic and real stereotyping and discrimination of persons and groups based on their chronological age and/or their belonging to a particular cohort/generation.' This definition also covers the issue of the 'new ageism' (Kalish 1979), a paternalistic approach to older adults that constructs a passive role of needing care and protection. In this text, I argue that the concept of active ageing as used in the public sphere and in policy-making, despite attempts to be inclusive, is actually covertly ageist, as it mainly homogenizes on the basis of age (van Dyk 2014). The productivist reduction of the concept leads to an even greater increase in activity and in stigmatization of the pension. Ageism can be seen in the increased entitlement to the usefulness of young olds and in the

\footnotetext{
1 This paper has been written as part of the Taking Age Discrimination Seriously project, based at the Institute of State and Law (Prague) and funded by the Grantová Agentura České Republiky (Grant number 17-266295).

2 Address: Mgr. Marcela Petrová Kafková, Ph.D., Office for Population Studies, Faculty of Social Studies, Masaryk University, Joštova 10, Brno 60200, Czech Republic and Institute of State and Law, Praha, Czech Republic. E-mail: kafkova@fss.muni.cz
} 
pressure on them to be economically productive, to care for their family members, and at the same time to fulfil the ideal of the older adult enjoying leisure and self-development activities (Petrová Kafková 2015; Vidovićová 2018). The young olds who do not achieve this demanding ideal can be even more stigmatized (Higgs - Gilleard 2015). Given that the ideal of productive young olds approaches the 'third age' ideals (Laslett 1989), it is also largely determined by class and therefore economically conditioned (Gilleard - Higgs 2000). People already experienced a higher risk of exclusion in previous life stages are in higher in older age (Foster 2018; Phillipson 2018; Taylor - Earl 2016). The empirical evidence for this inequality is mainly from the British environment; in the Czech environment, this issue has not yet been fully addressed, although the critical and reflective view of active ageing is strongly represented (Hasmanová Marhánková 2014, 2013; Petrová Kafková 2015). This paper is focused on two questions: Are current young olds overloaded by their social roles? And if so, is it possible to find an economic conditionality for this overload? In other words, does the need to balance more social roles more negatively affect young olds with lower economic capital? In addition, women are more likely to work as caregivers (Přidalová 2007); therefore, the gender conditionality of this experience seems significant.

\section{Young old and active ageing concept}

The young old is quite a newly established period of the life course. It is not precisely delimited by age, and in this way it is similar to the beginning of old age. It is the period approaching retirement. Young old is a life stage defined by a typical combination of some aspects of ageing (changes in physical and cognitive capacity) and certain demands on the individual. The demands are dual: the original demands are work, combined with parental and social responsibilities; the new demands include caring for ageing parents and grandchildren, as well as active enjoyment of leisure time. Young old as a new life stage arose thanks to increasing longevity and improving health. The parents or in-laws of the young olds are still alive, and many young olds also have grandchildren. At the same time, the retirement age is increasing, and older adults are pushed to be active, in the economic sense as well as in their free time. The current form of ageing is mostly conditioned by the concept of active ageing, which dominates both professional and public discourse. Active ageing calls for all-around activity, but this raises questions: What do young olds really do? How do they balance all their social roles? Are they overburdened by their care and work responsibilities? How do they negotiate their responsibilities and hobbies within a wider family setting? To what extent 
do they have agency to affect their day-to-day regime? Are they conditioned by the active ageing concept?

Until recently, population ageing was considered to be a potential threat to economic growth and thus to social cohesion (Walker 1990). The projected rising costs of pensions, health, and social care were the main reasons for implementing reforms and reopening the debate about the nature and sustainability of intergenerational equity. In an economizing perspective, this negative view of ageing persists. The promotion of active ageing policies is motivated by concerns about the intergenerational conflict, namely the fear of a breach of the existing intergenerational agreement by increasing the number of older adults and thus by decreasing resources to their care (Walker 1990). Concern about the rising costs for the state as a result of population ageing has led some countries to engage in anti-welfare politics, but the unintended consequence can be the opposite: an increase in the intergenerational conflict (Walker 1990), even though the fear of that conflict was the incentive to change the policies. The concept of intergenerational justice is used to assert fairness for the younger generations, which anticipate being disadvantaged in favour of the generously supported generations of older adults, and to justify neo-liberal reforms that reduce the unsustainably generous welfare state. Hess et al. (2017) used Eurobarometer 2009 data to show that there is a moderate intergenerational conflict among Europeans, but this is not affected by increasing population ageing, so it is not greater in countries with a higher share of older adults. The question remains whether the fear that older adults will draw 'too many' resources does not lead to the opposite pole of intergenerational inequality, in which young olds are heavily burdened by the demographic transformation of society.

Walker (1990: 387) asserts that the whole concept of intergenerational justice is incorrectly defined and poses a significant risk to the basis of politics. Intergenerational justice directs attention to the differences between unclearly defined age categories or generations and overlooks the inequalities within the age cohorts (Binstock 1985), which are increasing (World Bank 1994). The dominance of active ageing highlights age differences at the expense of other factors. Based on an analysis of the British political scene, Foster (2018) notes that most of the political debate on ageing and the pension system of the last decade has focused on prolonging the retirement age and longer employment. This is not just the case of the United Kingdom; it also applies in the Czech Republic. Active ageing is thus understood narrowly in its reduced productivist version, and this reductionist view justifies the need to increase the employment of older workers, even during the last economic recession or in the Czech Republic, where the employment of older workers is high for Europe on a long-term basis and currently is above average (Český statistický úřad 2012). 
Flexible employment conditions, which were more frequent during the economic recession, often aggravate the situation of already disadvantaged workers (Taylor - Earl 2016). In the United Kingdom, most of the employment growth of older workers was because they became self-employed and typically had lower incomes than before. Similarly, Koenig et al. (2015) found in the United States that the new employment of unemployed people older than 45 years is often only part-time or with lower wages than their previous work.

A reductionist view of active ageing brings the danger of the new ageism, requiring endless employment and perceiving work activities as a new legitimization of adult identity (Taylor - Earl 2016: 254). The emphasis on productivity excludes those who are not on the labour market and increases the risk of ignoring their contributions to society (Boudiny 2013). Extending the retirement age is linked to narratives of not becoming a burden on society (Taylor - Earl 2016). An example is the recently constructed Active Ageing Index (Zaidi 2015; Zaidi et al. 2012), which gave an entirely dominant position to economic activity, with the employment of the age cohorts of older adults constituting one of four domains of this composite index (Vidovićová Petrová Kafková 2016) ${ }^{3}$. Similarly, Moulaert and Biggs (2013) argue that active ageing has become a legitimization of itself through social inclusion in the labour market. Timonen (2016) shows that successful ageing ${ }^{4}$ is in fact highly class conditioned. In fact, the third age is a very desirable cultural image, but it is only available to the middle class (Gilleard - Higgs 2000; 2005). The productivist approach also disadvantages women who often have a different career path, more often working part-time and leaving the labour market to perform care work (Foster 2018). This disadvantage for women is also evident in the results of the Active Ageing Index in a gender gap that favours men (Zaidi 2015). Although these criticisms are aimed primarily at productivist reductions of active ageing, they also apply to the WHO (2002) definition. The original definition inseparably includes these exclusionary aspects.

The overestimation of the importance of generation or birth date detracts from finding solutions to population ageing through examining other sources of inequality, such as income, gender, and partnership status, as well as those stemming directly from state social policy. Older adults, like young people, are divided by social classes and socio-political consciousness (Walker 2012: 816). The current employment policy is applied regardless of the real employment opportunities due to, for example, the health status conditioned by previous

\footnotetext{
3 Employment rates and health access are the main causes of the low position of Slovakia in the Active Ageing Index. Slovakia was 25th out of 28 countries in 2014 (Petrová Kafková 2018).

4 The concepts of active ageing, successful ageing, and third age could be considered synonymous in this context, although they refer to slightly different concepts.
} 
career experiences (Phillips 2018). Olshansky et al. (2012) confirmed increasing inequalities in life expectancy by education and race in the US, calculating that in 2008, educated white men had 14.2 years higher life expectancy than black men with lower education. The authors, on the basis of these findings, wrote of the existence of at least two 'Americas' divided by education and racial affiliation. The trend of increasing inequalities in health is also evident in the Czech Republic, where the male life expectancy at 60 years varies greatly according to education; these inequalities are among the highest in Europe (Český statistický úrad 2012). Life expectancy in the Czech Republic at the age of 60 indicates that higher educated men have a life expectancy similar to women; men with below-university education seem to be disadvantaged in life expectancy with a five-year difference between the most educated and the least educated men. The SHARE data analysis confirms the socio-economic determinants of health in older age; people with lower education and lower income have a greater chance of decreasing health and quality of life regardless of age in the Czech Republic (Petrová Kafková 2016). Apart from class inequalities and health inequalities, ethnic and gender inequality, as well as inequalities between different cohorts of older adults (Walker 2012), are typically overlooked.

As Sýkorová summarizes (2006), the older adults in Western countries are generally considered as relatively wealthy; in the Czech environment, they are predominantly perceived as poor. This is despite the fact that the poverty risk rate for people receiving retirement pensions is one of the lowest in Europe (Vidovićová et al. 2015b). However, as the authors specify, in the retirement group "women are three times more likely to be at risk of poverty than men. For women, there is a predominant increase in the risk of poverty with increasing age' (Vidovićová et al. 2015b: 27). Other countries shows a significant tendency to accumulate the disadvantages experienced during older life (Willson - Etherington 2016). Formosa and Higgs (2015) recall the key importance of class and hence economic capital for gerontologists of the 1970s and 1980s and demonstrate its crucial influence even today. Czech sociology and gerontosociology have focused on the economic situation of older adults, but mainly from the perspective of the risk of their poverty and social exclusion; economic capital or class is seldom perceived as one of the fundamental stratification elements of the older adult population.

Retirement typically means more time devoted to some activity at home or some hobby (Scherger et al. 2011). In the UK environment, Scherger et al. (2011) confirmed the influence of socio-economic position on activities, as people with higher education and more qualified employment are more likely to increase their leisure activities or start new ones as they get older, while people in the lower classes diminish their activities. 
Hubatková (2018: 78) found that Czechs in their 50-70s have on average seven social roles, with a small but statistically significant decrease in their number with age. Those with a greater number of social roles experience even greater stress; at the same time, they have a better sense of well-being than those with fewer roles. A higher number of roles brings a higher sense of role overload. It seems that coping with many social roles can be stressful, but it gives a sense of usefulness and harmonizing the roles then seems to be a source of satisfaction and fulfilment. Those who volunteered or learned new roles or hobbies felt more stressed. The increase in stress with the number of roles is mainly due to the role of the employed worker; the increase in well-being with the number of roles and is mainly linked to the role of 'active ageing' (Hubatková 2018).

The caring role of grandparenting is understood by Czech young olds to be one of the most important in their lives; a role that brings them the most satisfaction (Vidovićová et al. 2015a). The authors conclude that grandparenting can serve as a positive source of life satisfaction. Caring obligations tend to accumulate, which is true in the Czech environment and, according to SHARE data, across Europe (Železná 2018). Grandparenting is most often provided by individuals who are also caring for their parents. For the Czech environment, there is empirical evidence that the accumulation of these roles leads to the feeling of role overload in about half of people in their 50s to 70s (Vidovićová 2018). This raises the questions: Is a feeling of role overload or the stress resulting from it conditioned by the socio-economic status of the individual? Is coping with role overload conditioned by economic capital?

\section{Methodology}

To answer these questions, we applied mixed methods using a secondary analysis of quantitative and qualitative data from the research project 'Role Overload: Grandparents in the Era of Active Ageing' (GA13-34958S) to capture the relationship between the feeling of role overload of young olds and their economic capital. Quantitative analysis is based on the 'Life Role' Survey conducted in September 2014 through a standard face-to-face questionnaire survey using computer-assisted personal interviewing (CAPI) in the Czech population aged 50 to 70 with an average interview length of 43 minutes. The resulting sample of 730 respondents obtained by quota selection is representative by gender, age, education, size of place of residence, and NUTS 3. Quotas were compiled on the basis of census data from the Czech Statistical Office in 2011. The sample is $53 \%$ women. In terms of education, the sample is structured as follows: $16 \%$ of people with elementary education, $42 \%$ vocational schools, $30 \%$ secondary education, and $13 \%$ university graduates. 
Sixty percent of respondents (56\% of women and $65 \%$ of men) were married; $20 \%$ of women and $8 \%$ of men are widowed. Regardless of the form of cohabitation, $70 \%$ of respondents said they currently have a partner. About one quarter $(26 \%)$ live in a single household and $49 \%$ in two-person households. In terms of economic position, $40 \%$ of respondents are employees (both sexes), another $40 \%$ are retired (43\% women; $36 \%$ men), and $6 \%$ are working pensioners. Self-employed persons are $9 \%$ : women $5 \%$; men $15 \%$. Women are twice as likely to be unemployed or in households then men (4\% and $2 \%$ respectively). As some ageing policies target people from the age of 50 , the original age structure of the sample is maintained, with the following distribution: $50-54$ years $(24 \%), 55-59$ years $(27 \%), 60-64$ years $(27 \%)$, and 65-70 years $(23 \%)$.

Our principal research interest in the social roles was addressed with the question, 'What are all the roles in your present life?' Respondents could choose from 15 roles, from which a cumulative index was then created, with roles of 0 to 15 . These were the following roles and their share in the file: spouse (partner) (69\%); parent (90\%); adult child (41\%); grandparent (62\%); employee or self-employed (56\%); friend (91\%); volunteer (7\%); new things learner (54\%); patient (41\%); carer (24\%); believer (25\%); sibling (79\%); hobby enthusiast (42\%); child-in-law (31\%); another important role $(1 \%)$.

The economic capital was measured by two variables: objective and subjective. Thus, the current household income was surveyed on an 18-point scale, with an average and a median value of 22,001 to 25,000 CZK (862 to $980 €)^{5}$. For further analysis, the scale was trichotomized. The subjective feeling of wealth was determined by the question: 'In terms of your assets, savings, real estate, etc., do you consider yourself to be rather rich or rather poor?' Respondents were asked to use a scale from 1 - poor to 10 - rich. On average and median, they set their wealth to the middle category of 5. For further analysis, the scale was categorized as poor (19.7\%), middle (74\%), and rich $(6.2 \%)$.

The free time was investigated with the question: 'When looking at a typical day, would you say that: 1 . you have almost no free time (10\%), 2. you have a little free time $(52 \%)$, 3. you have quite a bit of free time $(32 \%)$, or 4 . you have lots of free time (6\%)?'

Difficulties with role harmonization were explored with two questions: 'We were talking about various activities that people of your age do. If you think about the activities that you said you do, could you say how difficult it is for you to harmonize all of them?' with four possible answers: very difficult (4\%),

\footnotetext{
5 I am aware that resources are often unequally distributed in households, but in this survey, the income of the whole household was asked. The measure of the income of the whole household is appropriate because, for many older adults, the presence of two incomes/pensions prevents poverty.
} 
quite difficult (31\%), not very difficult (47\%), and not at all difficult (19\%). And 'How heavy is the load for you?' with four possible answers: very heavy load $(5 \%)$, quite heavy load $(35 \%)$, quite easy load $(47 \%)$, and no load $(14 \%)$. In further analysis, the first two categories were followed.

The qualitative part of the research is based on an analysis of 30 in-depth interviews with 32 interviewees ( 21 women and 11 men aged 56 to 82, average 65 years) conducted in 2013 and 2014. Five of the interviewees were older than 70 years old, but they belong to the young old category in terms of their lifestyle and their continuing employment, or they were narrating their previous experience as young olds. Even with a limited sample size, efforts were made to look for geographical diversity (people from large, medium, and small towns and villages from seven different regions of the Czech Republic were interviewed) and, above all, the diversity of experiences with different combinations of roles and role sets. Twenty of the total number of interviewees lived in a partnership (three couples were interviewed together), eight were divorced, three were widowed, and one woman was single. Seven respondents worked and were below retirement age; six of the respondents who were of retirement age still worked. They also varied in the number of grandchildren (from 0 to 8; on average, 1.6) and the intensity of care or experience of care for older relatives (e.g. parents). In the sample, three people had a vocational education, nine had a secondary education, and more than half of the sample were university graduates. Interviews were anonymized during transcription and nicknames are used. Part of the interviews was a short questionnaire identifying the subjective and objective economic status of interviewees, similar to the survey. Concerning the subjective evaluation of their economic situation, 5 claimed poor, 13 middle, and 12 rich. They, therefore, have a higher degree of economic capital and education and this specificity of the interviewees is perceived in analyses. The analysis was conducted in accordance with the principles of thematic analysis (Boyatzis 1998), the Atlas.ti program was used, interviews were repeatedly read, and the passages were assigned codes for which similarities and differences were sought in the next step. Interviews were semi-structured. The average interview lasted 87 minutes.

\section{Results}

First, we looked at the roles that young olds fulfil, the concurrence of the roles, and the ways that young old cope with them. The interviewees usually describe a busy day structured between work, hobbies, and care for grandchildren or older relatives. Adriana (61-year-old) described a day that was typical in terms of its high activity: 'I get up at half past four. I exercise for an hour and a half 
... clean up. I leave for work at quarter to seven. I at work from seven to quarter past three. After work, I never return directly home. I have a person I care for or help take care of ... so either I go to visit her or I go to see a grandchild but also have my activities... And I also have a lot of friends so I always get home around eight or nine. Taking care of the ca... And sometimes ironing, I do some little cleaning, and I go to bed.' On the weekends, Adriana takes care of her grandchild. The amount of time spent at work, often despite reaching retirement age, is considerable, which is probably due to the significant share of interviewees being more educated. The vast majority, like Adriana, regularly devote time to leisure activities. These include a wide range of sports, gardening, cultural events, membership in various clubs and committees, as well as meeting friends. The daily regime reflects the individual preferences of young olds, but the situation is negotiated within a wider family, i.e. between generations, and is based on possible care needs of young or disabled ones. As part of this negotiation, some interviewees have left their jobs or significantly reduced their workload to be able to care for their grandchildren more and allow their daughter or daughter-in-law to return to work. The workload reduction for the sake of grandchild care is only presented in women's stories; men provide care in their free time. Economic reasons are not explicitly mentioned; the type of the daughter's employment is noted and the aim to relieve them of the daily care of young children, which is perceived as demanding. Blanka (63-year-old) stated that she had wanted to remain economically active after finding a job after a period of frequent job change: '... I would have continued in this job, but my daughter had an offer at that time, while she was still on maternity leave, to work at least part-time ... And because of my own experience, I remember that when I had been at home with my children for five years, then I could not talk about anything but nappies. (laughter) So I wanted it, so I'm there. I only worked for one year past retirement age, and then I started helping my daughter with her children.' So Blanka gave up her job to enable her daughter to return to the labour market, despite her desire to remain economically active. Similarly, Christina (65-yearold) started to work only on weekends and cared for her grandchild every morning to enable her daughter to keep her private practice. This lasted almost three years, until the grandchild entered kindergarten.

In contrast, Sylvie (66-year-old), who supports her divorced daughter financially and cares for the grandchild two afternoons a week and part of the weekends, has indicated economic reasons for her continued employment. Sylvie spoke of her daughter's difficulties in finding a job and explicitly states: 'I cannot tell her to go work somewhere and I'll take care of the little one. What I earn, because of where I already am, I have no idea what she would have to do to earn. Also, as long as I can work, until I'm demented and unable 
to work, I want to work.' But the implicit reason for this attitude may be the daughter's medical diagnosis and the good living standard that Sylvie is able to provide with full-time work and pension.

The daily programme of young olds might seem too busy. Women perform on average the same number of roles as men. People with higher economic capital have more roles, and the number of roles is more closely related to household income (Pearson's $\mathrm{R}=0.434, \mathrm{p}<0.01$ ) than to subjective wealth (Pearson's $\mathrm{R}=0.225, \mathrm{p}<0.01$ ). Rich people, therefore, fulfil more social roles, even though our list mainly includes family and other roles primarily not requiring financial capital. The gender perspective reveals an interesting difference between household income and subjective wealth: household income is more closely associated with number of social roles in case of men (Pearson's $\mathrm{R}=0.467$ vs. $0.428, \mathrm{p}<0.01$ ), subjective wealth is more closely associated with number of social roles in case of men. Men have a slightly smaller positive statistical relationship between the number of roles and subjective wealth than women (Pearson's $\mathrm{R}=0.213$ vs. $0.238, \mathrm{p}<0.01$ ). The number of roles is more dependent on household income for men.

In one question, respondents were asked to list the two or three roles that are the most difficult to harmonize; $49.3 \%$ explicitly stated that they do not have any problem with balancing the roles. The majority $(50.7 \%)$ of the respondents have difficulty reconciling their roles, and most often blame their roles as workers, partners, and grandparents. The most important roles were evaluated as the family roles (partner, parent, and grandparents); the role of the worker was considered to be the most important by only $5.5 \%$ of respondents. It is logical that people with multiple roles feel they have less free time. People who have almost no free time in their day have an average of 7.5 roles, while those who have a lot of free time only have 5.0 roles. The decrease in free time with the increase in the number of roles is confirmed by their moderate association (Pearson's $\mathrm{R}=0.303, \mathrm{p}<0.01$ ). The perception of the amount of free time is gender-based. Women who feel they have almost no free time have on average 8.0 roles; men who feel similarly have 6.9 . Women who feel they have a lot of free time have on average 5.3 roles, men have 4.8. The statistical association is closer for women than for men (Pearson's $\mathrm{R}=0.316$ vs. $0.285, \mathrm{p}<0.01$ ).

However, in the qualitative interviews, a day full of activities and fulfilling of social roles is only rarely attended by stress and a sense of overload. In their narratives, stress is mentioned in memories of past care for parents or other older relatives. The stress of care emerges from the time demands, but especially from the psychological load of this care, when 'you see how these people wither away and you cannot really do anything.' Adriana describes her experiences during a period of intensive care for close relatives: 'Then I had my uncle and aunt, also childless, whom I cared for, but they were already very ill 
at that time. There it was difficult. I went there in the morning before I went to work, at noon, to bring them lunch, and in the afternoon either to visit one in the hospital or wherever he/she was, and home to see the second one. And it was quite demanding.' Moreover, intensive care can take several years when more loved ones become progressively needy. Beata (67 years old) was taking care of her parents and then of her aunt, which meant a combined 10 years of care. Similarly, Ursula (79 years old) remembered the very intense half-year care of her husband when she took unpaid leave at work, and after his death, her mother's condition deteriorated, and she took care of her. She provided this intensive care when she was 70 years old. And while the concurrent need for intensive care for older relatives and grandchildren is not very common, some interviewees experienced such a period. Sylvie (66 years old) passed a period of intensive care for her parents with the help of a nursing caregiver, devoted herself to her grandchild and had full-time work, and then attended to her husband's serious illness. When talking about providing care, the interviewees did not explicitly mention economic difficulties. The economic situation as a limiting element in care was rather presented in the context of providing care for the grandchildren and filling the time with them. The economic situation was mentioned in the interviews implicitly in the form of the nature of employment that enabled the interviewees to reconcile full-time work with care.

The survey data shows that, in general, more roles lead to a sense of role overload, which is logical, although the relationship of both variables is rather weak $($ Eta $=0.236, \mathrm{p}<0.01)$ and we can assume that other factors have a significant influence. Gender does not interfere with this relationship. The effect of economic capital on the sense of role overload is not unequivocal. Higher household income leads to problems of role reconciliation, although the mutual statistical link is weak $($ Eta $=0.218, p<0.01)$, subjective wealth does not influence the difficulty of balancing roles.

If we look explicitly at the difficulty of balancing the roles, $34 \%$ of respondents find it difficult to reconcile all their activities (more specifically, $4 \%$ see it as very difficult; $31 \%$ as quite difficult). The reconciliation of roles presents a heavy burden for $40 \%$ of respondents (very heavy for $5 \%$ and fairly heavy for $34.6 \%$ ). The share of respondents considering reconciliation difficult is different between men and women: $10.8 \%$ more women than men consider the necessity of this reconciliation to be a major burden. Due to the different structure of samples of qualitative and quantitative data, these results are not in contradiction, as evidenced by the following analysis of the impact of economic capital.

Economic capital has an impact on the sense of burden. Household income does not affect the sense of burden; subjective wealth has a considerable 
impact. With the subjective wealth decrease the difficulty with role harmonization, as well as the share of respondents with very heavy harmonization. The differences are substantial (see Table 1). In terms of economic capital, the gender influence remains the same, i.e. men and women experience the load of harmonization differently. The share of respondents feeling a heavy load is greater among poor women $(51.6 \%)$ and the lowest among rich men $(20.0 \%)$. The difference is more than $30 \%$. It seems therefore that even in this case, the theory of cumulative (dis)advantage (Dannefer 2003) applies. The household income influences dependent variables less. The lowest share of those who consider reconciliation to be difficult and a heavy load is among middleincome men and women. The low and high income households feel more difficulties and a heavier load, although the differences are marginal. The differences are especially in the feeling of the great load of harmonization. A higher share of women than men consider reconciliation to be a great burden. We can assume that the same proportion of low- and high-income respondents feeling harmonization to be a heavy burden is based on different causes. The low-income respondents cite the difficulty as due to the lack of economic capital, while the high-income respondents find difficulty in the larger number of roles they want to fulfil.

Table 1: Feelings of role overload according to economic capital (\%)

\begin{tabular}{llllllll}
\hline & & \multicolumn{3}{c}{ Harmonizing is difficult } & \multicolumn{3}{c}{ Harmonizing is the great load } \\
\cline { 2 - 9 } & & Total & Men & Women & Total & Men & Women \\
\hline \multirow{3}{*}{ Subjective wealthy } & Poor & 41.5 & 42.4 & 40.6 & 48.8 & 45.8 & 51.6 \\
\cline { 2 - 9 } & Middle & 33.2 & 30.8 & 35.4 & 38.2 & 31.6 & 44.3 \\
\cline { 2 - 9 } Household income & Rich & 22.5 & 23.8 & 21.1 & 23.7 & 20.0 & 27.8 \\
\hline & Low & 32.3 & 31.0 & 33.0 & 39.9 & 34.5 & 43.0 \\
\cline { 2 - 9 } & Middle & 32.9 & 29.7 & 36.6 & 34.5 & 29.9 & 39.3 \\
\cline { 2 - 9 } & High & 35.9 & 34.5 & 37.5 & 39.9 & 36.9 & 43.0 \\
\hline
\end{tabular}

Respondents cite the role of worker as a cause of role overload, and there is a significant difference in perceived burden according to economic activity or inactivity. Reconciling their current roles is perceived as difficult by $38.2 \%$ of the economically active and $28.3 \%$ of the economically inactive respondents. This harmonization presents a heavy load to $42.9 \%$ of the economically active and $35.2 \%$ of the economically inactive respondents. Of course, the age of the respondents also influences the number of roles performed: its number slightly decrease with age. The role of the worker is crucial because it is perceived as the most difficult to reconcile with the other roles and as the most demanding. For most interviewees, the role of worker provides more than financial security, even in situations where they have managed to adjust the workload 
after retirement to suit them. Zdeněk (62 years old), who will soon reach retirement age, plans to remain in employment because: 'I was gradually deprived of some functions, and with those functions, it was even more time consuming and the work was more, and that was where I had to take the work home sometimes. Yeah, in the evening ... But this has fallen off, so when they take away the functions, they also take away the worries ... I personally liked the higher workload, of course, but now I'm used to it, and I would say that the present state is nice, so I do not complain ... Now the job does not interfere with my personal life. It does not limit me at all. And now I'm not going to change anything. So it's good.' Zdeněk uses his free time for family, sports, and other leisure activities. And while he plans to remain in his current job after retirement, part of the interviewees have completely changed their profession. Cilka (66 years old) did not want to continue in private practice after her husband's death, and instead worked in a good position in tourism. This seasonally demanding work does not prevent Cilka from maintaining intensive family relationships and frequent care of the grandchild.

Stress and difficulties with reconciliation are primarily caused by unsatisfactory employment associated with the uncertainty of retention, and thus the stress of potential loss of employment in pre-retirement age. Žaneta (56 years old) describes the fear of being fired: 'Everybody tells me to get ill, and then get pre-retirement. I thought I would stay there. At least two more years of work. Well, with such people probably there. I can stand a lot, but this is probably not the case. I'll have to find a new job, but at my age, who will employee me? So I'll see ... If it was as formerly, I'd been retired for two years now. I'd have a grandchild here all the time.' Žaneta is an exception in that she does not want to work after reaching the age of retirement, and at the same time is one of the few interviewees with lower qualification. Žaneta perceived her economic situation as poor. She spends her free time gardening and with her grandchild, which is also her preferred occupation in retirement. She thus confirms the results of the quantitative data analyses that young olds with lower economic capital have less activity and greater difficulty in role reconciliation. More interviewees assessed their economic situation as poor, but they seemed to have very active lifestyles. The choices of interviewees may explain this, where multiple roles were preferred. Therefore, it may be more informative to look at differing strategies for managing multiple roles, rather than at different lifestyles.

\section{Conclusion}

The concept of active ageing strongly determines life in old age. Young olds fulfil a large number of social roles. Their day is divided between economic 
activity, family care, sports, and hobbies. Managing the concurrence of a large number of activities is facilitated by a full daily schedule and by the negotiation of the extent and form of provided care. Based on both qualitative and quantitative data, we can state that Czech young olds are a solid part of their multigenerational families, taking care of the youngest and oldest family members. They understand their family roles as essential among other roles and as a source of pleasure. The grandparent role in particular is actively sought but is not understood as given. Its form and extent is negotiated by men and women in the context of the needs of all generations, as well as in the context of their own preferences (Hasmanová Marhánková 2013). The number of fulfilled social roles indicate their concurrence for the young old. About half of them feel overloaded, even though they only fulfil the activities that are promoted by the productive versions of the active ageing concept. The concurrence of many roles along with the productive ethos of selfindependence could lead to the disruption of intergenerational justice, but not in the supposed direction of older adults benefiting at the expense of younger generations, but to the detriment of young seniors. Ageing policies are consistently aimed at the elderly, but our analysis also shows that the scope of the aid is negotiated intergenerationally to the detriment of young olds. The economic activity of daughters with young children is more valued than the economic activity of young olds, and some young olds leave their employment or reduce their working hours to allow a younger generation to return to the labour market. This solution is gender-specific and concerns only women.

Maintaining economic activity is one of the key elements of ageing policies. In the Czech environment, programmes increasing the retirement age and specific employment programmes for older workers are being gradually implemented that are considerable in the European context (see above). The survey data shows more than half of the young old population is economically active, which is logical with respect to scrutinized age. Although many of respondents are economic active, their role as a worker is not very important for them. They consider the worker role to be the most time consuming and as the main cause of their role overload. However, the interviewees' stories show that this role has more meaning beyond a financial one. Their good employment position, acquired through high qualification and long practice, allows them to fulfil other important roles concurrently. High employment despite retirement age is likely to be conditioned by their high level of qualification, with only three of the interviewees not finishing secondary school or higher education. Only one interviewee without secondary education (Žaneta) perceived role harmonization as demanding and spoke of the need for rest after working and caring for an older relative. In her narrative, there is uncertainty about the near future associated with the fear of losing her job. 
Although young olds fulfil a large number of roles, the feeling of role overload was present in only half of them. It should be remembered that the number of roles is positively associated with well-being (Hubatková 2018). There is not a significant difference between men and women in the number of roles and in the perceived difficulty of role balancing. Women more often than men feel the necessity of balancing roles as a great burden. In interviews, the feeling of role overload is connected especially with periods of intensive care for disabled relatives, usually a parent or husband.

Economic capital plays a significant part in the role overload and in coping with it. People with less economic capital fulfil fewer roles, which could lead to better management, but it does not. The subjective feeling of poverty brings a feeling of more difficulty in role balancing and a feeling of greater burden. The differences between the poor and the rich are considerable. In the perceived difficulty of harmonization, the difference between poor and rich is almost $20 \%$; in the perception of the great load of harmonization it is $25 \%$. The same applies to men and women. However, women feel the need for reconciliation to be a heavy burden more often than men do. The need to harmonize all their roles represents a great burden for $51.6 \%$ of the subjectively poor women. It seems that the subjective perception of economic capital is more important than household income in managing role balance.

Czech young olds fulfil a large number of social roles. Their acceptance of the active ageing concept could be presumed. A substantial part of young old concurrently manage many social roles. Economic capital facilitates the management of the multiple role sets. This is reflected in the busy schedules of the majority of the interviewees with higher economic capital. Yet even their narratives contain memories of periods in which managing all their roles was very demanding. It therefore appears that intergenerational justice is currently diverted to the detriment of young olds in terms of the number of duties and social roles, and the concept of active ageing contributes to this. The active ageing concept is ageist in its homogenization of all young olds on the basis of age regardless of other characteristics. This text demonstrates that in the Czech environment, the number of social roles and their reconciliation are conditioned by economic capital and gender. The number of roles and the possible challenges of their harmonization is not gender-based; the specific forms of care provision and the strategies used to manage all the roles are gender-based. The female gender together with low economic capital both have negative effects. The pressure to be active has different consequences and dividing the older population in terms of age or gender alone is insufficient.

Marcela Petrová Kafková is a sociologist and researcher at the Office for Population Studies at the Faculty of Social Studies, Masaryk University. Her 
long-term research interests are in the sociology of ageing and social gerontology. Her research concentrates on the issues of active ageing, intergenerational relations, ageing with disabilities, and the environmental determinants of ageing.

\section{REFERENCES}

BINSTOCK, R. H., 1985: The Oldest Old: A Fresh Perspective or Compassionate Ageism Revisited? The Milbank Memorial Fund Quarterly. Health and Society 63(2):420-451.

BOYATZIS, R. E., 1998: Thematic Analysis and Code Development: Transforming Qualitative Information. London and New Delhi: Sage Publications.

Český statistický úřad. 2012: Senioři v mezinárodním srovnání 2012. Available from: https://www.czso.cz/documents/10180/20567017/e-1417-12_vz.pdf/f0c808aa-4fd4$424 \mathrm{c}-8 \mathrm{ca} 7-\mathrm{cd} 608579 \mathrm{aecb}$ ? version $=1.0$

DANNEFER, D., 2003: Cumulative Advantage/Disadvantage and the Life Course: Cross-Fertilizing Age and Social Science Theory. The Journals of Gerontology Series B: Psychological Sciences and Social Sciences 58(6):S327-S337.

van DYK, S., 2014: The Appraisal of Difference: Critical Gerontology and the ActiveAgeing-Paradig'. Journal of Aging Studies 31:93-103.

FORMOSA, M. - HIGGS, P., 2015: Social Class in Later Life: Power, Identity and Lifestyle. Policy Press.

FOSTER, L., 2018: Active Ageing, Pensions and Retirement in the UK.. Journal of Population Ageing 11(2):117-132.

GILlEARD, C. - HIGGS, P., 2005: Contexts of Ageing. Class, Cohort and Community. Cambridge: Policy Press.

GILLEARD, C. - HIGGS, P., 2000: Cultures of Ageing: Self, Citizen, and the Body. Essen: Perason Education.

HASMANOVÁ MARHÁNKOVÁ, J., 2013: Aktivita jako projekt. Diskurz aktivního stárnutí a jeho odezvy v životech českých seniorů a seniorek. Studie. Praha: Sociologické nakladatelství.

HASMANOVÁ MARHÁNKOVÁ, J., 2014: Aktivní stárnutí jako idea, nástroj a kapitál. Kde hledat kořeny úspěchu koncepty aktivního stárnutí? Sociální studia (3):13-29.

HESS, M. - NAUMAN, E. - STEINKOPF, L., 2017: Population Ageing, the Intergenerational Conflict, and Active Ageing Policies - a Multilevel Study of 27 European Countries. Journal of Population Ageing 10(1):11-23.

HIGGS, P. - GILLEARD, C., 2015: Rethinking Old Age: Theorising the Fourth Age. Palgrave Macmillan.

HUBATKOVÁ, B., 2018: Number of Roles and Well-Being among Older Adults in the Czech Republic. International Journal of Ageing \& Later Life 11(2):61-85.

KALISH, R. A., 1979: The New Ageism and the Failure Models: A Polemic. The Gerontologist 19(4):398-402.

KOENIG, G. - TRAWINSKI, L. - RIX, S., 2015: The Long Road Back: Struggling to Find Work after Unemployment. Washington: Future of Work 50. 
LASLETT, P., 1989: A Fresh Map of Life: The Emergence of the Third Age. Weidenfeld and Nicolson.

MOULAERT, T. - BIGGS, S., 2013: International and European Policy on Work and Retirement: Reinventing Critical Perspectives on Active Ageing and Mature Subjectivity. Human Relations 66(1):23-43.

OLSHANSKY, S. J. et al., 2012: Differences in Life Expectancy Due to Race and Educational Differences Are Widening, and Many May Not Catch Up. Health Affairs 31(8):1803-1813.

PETROVÁ KAFKOVÁ, M., 2018: The Czech Republic and Slovakia - Shared Lives with Different Outcomes. Presentantion at Second International Seminar on the Active Ageing Index in Bilbao, 27-28 September 2018, Spain. Available at: http://www.unece.org/index.php?id=49105

PETROVÁ KAFKOVÁ, M., 2016: The "Real" Old Age and the Transition between the Third and Fourth Age. Sociológia 48(6):622-640.

PETROVÁ KAFKOVÁ, M., 2015: Aktivní stárnutí - př́iležitost nebo nové dogma? Pp. 65-76. In: H. Štěpánková, C. Höschl, L. Vidovićová: Gerontologie - současné otázky z pohledu biomedicíny a společenských věd. Praha: Karolinum.

PHILLIPSON, C., 2018: "Fuller" or "Extended" Working Lives? Critical Perspectives on Changing Transitions from Work to Retirement. Ageing \& Society 1-22.

PŘIDALOVÁ, M., 2007: Mezi solidaritou a konfliktem: zkušenost pečujících dcer a synů'. Sociální studia 4(1-2):219-236.

SCHERGER, S. - NAZROO, J. - HIGGS, P., 2011: Leisure Activities and Retirement: Do Structures of Inequality Change in Old Age? Ageing \& Society 31(01):146-172.

SÝKOROVÁ, D., 2006: Senioři v České republice. Mýty a jejich dekonstrukce. Sociológia 38(2):151-164.

TAYLOR, P. - EARL, C., 2016: The Social Construction of Retirement and Evolving Policy Discourse of Working Longer. Journal of Social Policy 45(2):251-268.

TIMONEN, V., 2016: Beyond Successful and Active Ageing: A Theory of Model Ageing. Policy Press.

VIDOVIĆOVÁ, L., 2018: The Expected, Evaluated, Perceived, Valued and Prevalent Social Roles of Older People: Are They by Consent? Pp. 39-54 in Building Evidence for Active Ageing Policies. Springer.

VIDOVIĆOVÁ, L., 2005: Věková diskriminace - ageismus: úvod do teorie a výskyt diskriminačních přístupů ve vybraných oblastech s důrazem na pracovní trh. Praha: VÚPSV.

VIDOVIĆOVÁ, L. - GALČANOVÁ, L. - PETROVÁ KAFKOVÁ, M., 2015a: Význam a obsah prarodičovské role u mladých českých seniorů a seniorek. Sociologický Časopis/Czech Sociological Review 51(5):761-782.

VIDOVIĆOVÁ, L. et al., 2015b: Př́íjmová chudoba a materiální deprivace seniorů: subjektivní a objektivní pohledy. Praha: VÚPSV.

VIDOVIĆOVÁ, L. - PETROVÁ KAFKOVÁ, M., 2016: Index aktivního stárnutí (AAI) v regionální aplikaci. Demografie : revue pro výzkum populačního vývoje 58(1):49-66.

WALKER, A., 1990: The Economic "Burden" of Ageing and the Prospect of Intergenerational Conflict. Ageing \& Society 10(04):377-396. 
WALKER, A., 2012: The New Ageism. The Political Quarterly 83(4):812-819.

WHO, 2002: Active Ageing: A Policy Framework.

WILLSON, A. E. - ETHERINGTON, N., 2016: Poverty, Income, and Wealth across the Life Course. Gerontology: Changes, Challenges, and Solutions [2 Volumes]: Changes, Challenges, and Solutions 137.

World Bank, 1994: Averting the Old Age Crisis: Policies to Protect the Old and Promote Growth. World Bank Publications.

ZAIDI, A., 2015: Active Ageing Index 2014: Analytical Report.

ZAIDI, A. et al., 2012: Towards an Active Ageing Index Concept, Methodology and First Results. UNECE Working Group on Ageing Fifth Meeting.

ŽELEZNÁ, L., 2018: Care-Giving to Grandchildren and Elderly Parents: Role Conflict or Family Solidarity? Ageing \& Society 38(5):974-994. 